Research Article

www.ijrap.net

\title{
A PRELIMINARY STUDY ON THE PHYTOCHEMICALS AND ANTIOXIDANT POTENTIAL OF GULGULUPANCHAPALA CHOORNA USED IN THE MANAGEMENT OF FISTULA-IN-ANO
}

\author{
Sruthi C.V. and Sindhu A.* \\ Research and development division, Factory, The Arya Vaidya Pharmacy Coimbatore Limited, India
}

Received on: 08/05/13 Revised on: 24/06/13 Accepted on: 13/07/13

\author{
*Corresponding author \\ E-mail: sindhu.sreejith@gmail.com \\ DOI: $10.7897 / 2277-4343.04412$ \\ Published by Moksha Publishing House. Website www.mokshaph.com \\ All rights reserved.
}

\section{ABSTRACT}

Fistula in ano is a common health problem affecting thousands of people worldwide. Oxidative stress is an important factor in the pathogenesis of ano rectal diseases. Depletion of intracellular antioxidants in acute oxidative stress increases intra cellular reactive oxygen species accumulation. Gulgulupanchapala Choornam is a polyherbal Ayurvedic preparation used in the treatment of fistula in ano. The present work aims on a preliminary study about the phytochemicals and antioxidant activity of gulgulupanchapala Choornam and to correlate with its usage in fistula in ano (Bhagandhara). The preliminary phytochemical study were determined using the methods by Harborne and the antioxidant properties were estimated by DPPH radical scavenging activity. From the observation, it was found that the product exhibited the presence of almost all the phytochemicals and also a higher antioxidant activity which may be a reason for its protective role in the management of fistula in ano.

Keywords: Gulgulupanchapala choorna, Phytochemicals, Antioxidant, Fistula in ano.

\section{INTRODUCTION}

Fistula in ano or Bhagandhara is a painful condition occurring in the peri-anal region. It is caused when vata dosha gets aggravated in the anal region. It vitiates the muscles and bones and gives rise to an inflamed eruption with pain, when this condition is left untreated the eruption undergoes suppuration ${ }^{1}$. Such eruptions developing on traumatic affliction and enhanced pressure in the peri-anal region and pelvic region accompanied with itching, pain, burning sensation swelling in these area are all prodromal symptoms to fistula in $\mathrm{ano}^{2}$. It is basically an infection of the anal glands, which when not managed appropriately results in suppuration and leads to a deep rooted abscess. Fistula in ano is successfully managed surgically for its non-recurrence. Even though it is a surgically managed condition there are formulations which are used in the treatment of bhagandhara. One such effective formulation is Gulgulupanchapala choorna. It is a unique combination of 7 herbs namely Commiphora mukul, Terminalia chebula, Terminalia bellerica, Embilica officinalis, Piper longum, Elettaria cardamom and cinnamon zeylanicum. Though it is indicated in bhagandhara, it is also cited to be effective in kusta (skin diseases), gulma (Flatulence) and in sinuses ${ }^{3}$. Various research studies reveals that most of these herbs posses antiinflammatory, antioxidant, antimicrobial and wound healing properties ${ }^{4-9}$. It is evident that the reactive oxidative intermediates formed during infections can damage normal tissues unless kept under control by antioxidants. It is seen that therapies based on increasing antioxidant potential, have a major impact on clinical infectious diseases like Fistula in ano (bhagandhara). In the current study this formulation was evaluated for its antioxidant properties and an attempt was made to correlate its antioxidant property and its function in the management of bhagandhara. The hexane, ethyl acetate and methanol extractives of the formulation was assessed and the preliminary phytochemical evaluation of these extractives were also performed.

\section{MATERIALS AND METHODS \\ Sample collection}

The sample for the study was procured from The Arya Vaidya Pharmacy (Coimbatore) limited, India.

\section{Solvent extraction}

The sample was subjected to successive solvent extraction in soxhlet apparatus using solvents in increasing order of polarity like hexane, ethyl acetate and methanol. The extracts were then concentrated and stored at room temperature for further analysis. The successive solvent extractives percentages were also calculated.

\section{Preliminary phytochemical screening}

The preliminary phytochemical analysis for the identification of various bioactive components were carried out for all the extracts by the method described by Harborne and Sazada et $a l^{10,11}$. The extracts were analysed for the presence of carbohydrates, phenols, flavonoids, tannins, steroids, terpenoids, alkaloids, cardiac glycosides, saponins, amino acids, fixed oils and fats. Phytochemical screening was performed using the following reagents and chemicals: Carbohydrates with Fehling's reagent and Molisch's reagent, phenols with 5\% ferric chloride, flavonoids by Shinoda test and lead acetate reagent, tannins with $10 \%$ alcoholic ferric chloride, steroids and terpenoids with concentrated sulphuric acid and chloroform, alkaloids with Hager's, Wagner and Dragendorff's reagent, cardiac glycosides with 5\% ferric chloride and glacial acetic acid, saponins by foam test and amino acids with ninhydrin reagent. 


\section{DPPH Radical Scavenging Activity}

The antioxidant activities of the various extracts of gulgulupanchapala choornam were estimated by DPPH (2'2-diphenyl-1-picryl hydrazine) radical scavenging activity $^{12}$. Briefly, to various concentrations of the sample, methanolic solution containing DPPH radicals
$(0.1 \mathrm{mM})$ was added and shaken vigorously. The reaction mixture was then left to stand for 30minutes in dark. After the incubation period, the absorbance was measured at $517 \mathrm{~nm}$ against the corresponding test blanks. The percentage inhibition of DPPH free radical was calculated using the formula, as given below;

$\%$ Inhibition $=(($ Control-sample $) /$ Control $) \times 100$

The sample concentration providing $50 \%$ inhibition $\left(\mathrm{IC}_{50}\right)$ was calculated from the graph of RSA percentage against sample concentration. Ascorbic acid was used as standard.

Table 1: Extractive percentages of Gulgulupanchapala choornam

\begin{tabular}{|c|c|}
\hline Extract & Extractive $\%$ \\
\hline Hexane & 5 \\
\hline Ethyl Acetate & 9 \\
\hline Methanol & 12.14 \\
\hline
\end{tabular}

Table 3: Antioxidant activity

\begin{tabular}{|c|c|}
\hline Extracts & *IC 50 \\
\hline Hexane extract & $460 \mu \mathrm{g}$ \\
\hline Ethyl acetate extract & $26 \mu \mathrm{g}$ \\
\hline Methanol extract & $16.5 \mu \mathrm{g}$ \\
\hline *Effective concentration for $50 \%$ inhibition
\end{tabular}

Table 2: Preliminary Phytochemical Screening

\begin{tabular}{|c|c|c|c|}
\hline Secondary metabolites & Hexane extract & Ethyl acetate extract & Methanol extract \\
\hline Carbohydrate & Present & Present & Present \\
\hline Phenols & Absent & Absent & Absent \\
\hline Flavonoids & Absent & Absent & Present \\
\hline Tannins & Absent & Present & Absent \\
\hline Steroids & Absent & Absent & Present \\
\hline Terpenoids & Present & Present & Absent \\
\hline Alkaloids & Absent & Absent & Present \\
\hline Cardiac glycosides & Absent & Absent & Absent \\
\hline Saponins & Present & Absent & Present \\
\hline Aminoacids & Absent & Absent & Absent \\
\hline
\end{tabular}

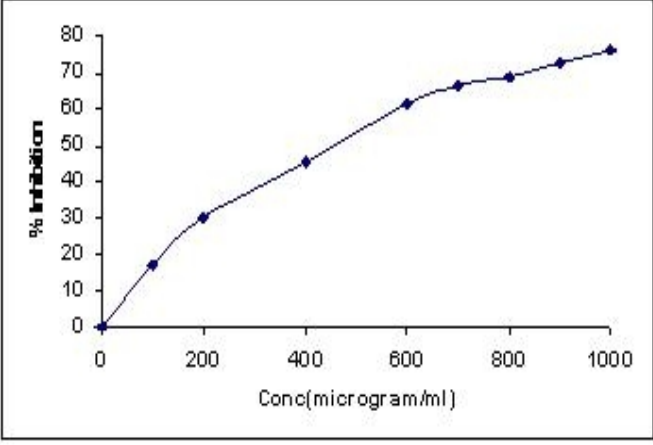

Figure 1: Antioxidant activity of hexane extract

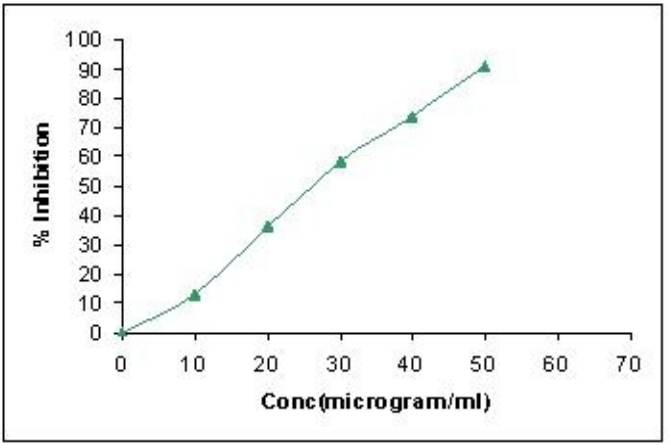

Figure 2: Antioxidant activity of ethyl acetate extract

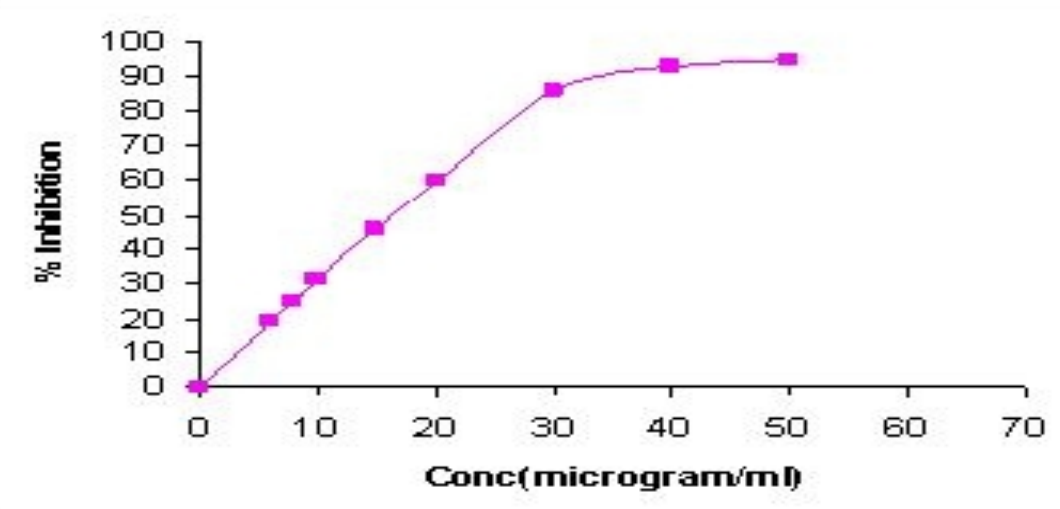

Figure 3: Antioxidant activity of methanol extract 


\section{RESULTS}

Extractive percentages and preliminary
phytochemical screening

The successive solvent extractive percentages of gulgulupanchapala choornam were given as in the Table 1. The preliminary phytochemical screening of the three extracts of gulgulupanchapala choornam revealed the presence of various secondary metabolites like carbohydrates phenols, tannins, terpenoids, saponins, fixed oils and fats. The results obtained were shown in Table 2. On comparing the result of the phytochemical screening, the phytoconstituents were found to be higher in methanolic extract. Carbohydrates, phenols, tannins, terpenoids, saponins, fixed oils and fats were identified in the methanolic extract. In case of hexane extract, the bioactive components present were carbohydrate, tannins, terpenoids, saponins, fixed oils and fats whereas in ethyl acetate extract carbohydrate, tannins and terpenoids were only present.

\section{DPPH radical scavenging activity}

The antioxidant activity of the various extracts of gulgulupanchapala choornam were analysed using the stable radical DPPH. The activity depends upon the ability of the extracts to scavenge these free radicals. The radical scavenging activity was found to be higher in the methanolic extract $(16.5 \mu \mathrm{g})$. The ethyl acetate extract possessed a better activity with an effective concentration of $26 \mu \mathrm{g}$. The least activity was found in hexane extract $(460 \mu \mathrm{g})$ (Table 3.). Figure 1, 2, 3 shows the graphical representation of the effective concentration required by each extract to quench the DPPH radical.

\section{DISCUSSION}

The various fractions of gulgulupanchapala choornam, showed the presence of almost all the phytoconstituents. Antioxidant activity using DPPH, demonstrated that this polyherbal preparation exhibited a high activity. In the present study, among all the fractions ethyl acetate and methanolic extract showed significantly higher inhibition percentage. Gulgulupanchapala choornam is a formulation indicated in the classical text Ashtangahridaya in the context of ano-rectal diseases (bhagandhara). Analysing the pathology of bhagandhara it is evident that a deep seated infection happens in the perianal region. During infection due to host defense mechanism, leukocyte microbial killing occurs which subsequently causes endogenous oxidation reactions where in reactive oxidative intermediates are formed ${ }^{13}$. Antioxidants neutralize and scavenge these free radicals generated in ano-rectal diseases and thereby reducing the pain, inflammation, swelling, itching and tenderness in these anatomical parts and also helps in a faster healing process $^{14}$. The antioxidant activity of gulgulupanchapala choornam there for facilitate in compacting the infectious basis of fistula in ano and helps in the management of bhagandhara.

\section{ACKNOWLEDGMENT}

We are grateful to Padmasree Dr. P. R Krishnakumar, Managing Director, The Arya Vaidya Pharmacy (Coimbatore) Limited, India for providing the facilities and encouragement to carry out the study.

\section{REFERENCES}

1. Murthy Srikantha KR. Susruta Samhita. Nidana sthana. $1^{\text {St }}$ ed, Varanasi: Choukambha Orientalia publishers; 2001.

2. Murthy Srikantha KR. Susruta Samhita. Nidana sthana. $1^{\text {St }}$ ed,Varanasi: Choukambha Orientalia publishers; 2001.

3. Vagbhata. Ashtangahridaya, Uttara Sthana.Vidhyodhini Commentory; $5^{\text {th }}$ ed, Varanasi: Choukambha Sanskrit Sansthan publishers; 1975.

4. Sahu Manoranjan, Nath Gopal, Singh Sanjay Kumar. Evaluation of Anti microbial properties of Guggulu. Journal of Ayurvedic Pharmaceutics and pharmacology; 2003: 1 .

5. Gujral ML, Sareen K, Tangiri KK, Amma MK, Roy AK. Anti arthritic and anti infective activity of gum guggulu (Balamodendron mukul hook). Indian journal of Physiology and pharmacology 1960; 4: 267-273. PMid:13709695

6. Al-zuhair H, Sayeh EL, Ameen HA, Al-shoora H. Pharmacological studies of cardamom oil in animals. Pharmacological research 1996; 34: 79-82. http://dx.doi.org/10.1006/phrs.1996.0067 PMid:8981560

7. Kamath Jagadish V, Rana AC, Chowdhury Anirban Roy. Prohealing effect of Cinnamomum zeylanicum bark. Phytotherapy Research 2003; 17: 970-972. http://dx.doi.org/10.1002/ptr.1293 PMid: 13680838

8. Muthusamy Senthil Kumar, Shanmugam Kirubanandan, Sripriya Ramasamy, Sehgal Praveen Kumar. Triphala Promotes Healing of Infected Full-Thickness Dermal Wound. Journal of surgical research 2008; 144: 94-101. http://dx.doi.org/10.1016/j.jss.2007 .02 .049 PMid:17662304

9. Rui Hai Liu. Health benefits of fruit and vegetables are from additive and synergistic combinations of phytochemicals. American Journal of Clinical Nutrition 2003; 78: 517-520.

10. Harbone JB (eds). Phytochemical Methods: A guide to modern techniques of plant analysis. $3^{\text {rd }}$ ed, Chapman and hall, London; 1998. p. 302

11. Sazada S, Verma A, Rather AA, Jabeen F, Meghvansi MK. Preliminary phytochemicals analysis of some important medicinal and aromatic plants. Advances in Bioresearch 2009; 3: 188-195.

12. Blois MS. Antioxidant determinations by the use of a stable free radical. Nature 1958; 29: 1199-1200. http://dx.doi.org/10.1038 $/ 1811199 \mathrm{a} 0$

13. Keusch GT. Antioxidants in infection. Journal of Nutritional Science and Vitaminology 1993; 39: 23-33. http://dx.doi.org/ 10.3177/jnsv.39.Supplement_S23

14. Arnold, Meghan MD, Barbul, Adrian MD. Nutrition and Wound Healing. Plastic and Reconstructive Surgery 2006; 117: 42-58. http://dx.doi.org/10.1097/01.prs.0000225432.17501.6c PMid:16799374

Cite this article as:

Sruthi C.V. and Sindhu A. A preliminary study on the phytochemicals and antioxidant potential of Gulgulupanchapala choorna used in the management of Fistula-in-ano. Int. J. Res. Ayurveda Pharm. 2013;4(4):519-521 http://dx.doi.org/10.7897/2277-4343.04412 